\title{
TP53 Mutation Carrier
}

National Cancer Institute

\section{Source}

National Cancer Institute. TP53 Mutation Carrier. NCI Thesaurus. Code C156121.

An individual who carries an inheritable mutation in the TP53 gene, without manifestation of any associated condition. 